DOI https://doi.org/10.30525/978-9934-26-073-5-2-4

\title{
«НА ДНІ» І. ФРАНКА ТА «ЗИМОВОГО ВЕЧОРА» Е. ОЖЕШКО: ТИПОЛОГІЧНИЙ ДИСКУРС
}

\author{
Оренчак О. О. \\ кандидат філологічних наук, \\ доцент кафедри романо-германської філології \\ та методики викладання іноземних мов \\ Міжнародного гуманітарного університету
}

Горанська Т. В.

старший викладач кафедри української та зарубіжної літератур Південноукраӥнського начіонального педагогічного університету імені К. Д. Уиинського м. Одеса, Украӥна

Діяльність I. Франка в царині польської культури, українськопольських літературних взаємин висвітлювалася в свій час українськими та польськими літературознавцями. Серед українських досліджень варто вказати на праці Г. Вервеса, М. Возняка, окремі студії Т. Пачовського, Я. Ривкіса, О. Грибовської, М. Косенко, І. Журавської тощо. Проте проблема типологічного дискурсу творів I. Франка та Е. Ожешко не знайшла і досі належного висвітлення.

Толерантність поглядів I. Франка, дбайливе ставлення до надбань культури польського народу, пильна увага до творчості польських письменників, потужний художній талант митця спричинили у свій час його велику популярність серед польської громадськості, особливо літераторів. Велике зацікавлення постаттю українського письменника виявила Еліза Ожешко, одна 3 найвидатніших представників польської реалістичної літератури. Так зав'язалося багаторічне дружне листування Франка з Ожешко, що тривало впродовж 1886-1888 років та залишило по собі цікаві спостереження, думки та творчі взаємини.

Е. Ожешко захоплювалася багатьма творами українського письменника, серед них, безперечно, великий вплив на ії творчу уяву справило оповідання «На дні» (1880). Знайомство 3 творчістю Франка i загалом 3 українською літературою припадає на період написання письменницею творів 3 життя білоруського селянства, які є вершиною творчості Ожешко, - «Низини», «Дзюрдзі», «Хам», роман-епопея «Над Німаном». Створюючи ці та інші твори, Ожешко, як типова 20 
представниця польського реалізму кінця ХІХ ст., вивчала багатий досвід сучасних їй літератур. У цьому плані досвід I. Франка прийшовся їй якнайкраще. У творах українського письменника, у його публіцистичних виступах, листах, Ожешко шукала відповіді на пекучі питання часу причини соціального i національного гніту народів. Під впливом демократичних поглядів Франка вона обстоювала національну незалежність, самобутню культуру, мову і традиції білоруського народу, тоді як польська шляхта намагалася полонізувати як білорусів, так й українців.

«Селянські» твори Е.Ожешко були новим словом у польській літературі і збагатили іiі не лише тематично, а й художньо. Саме в них найяскравіше виявився вплив української літератури, зокрема творчості I. Франка. Найпоказовішим 3 цього погляду $є$ оповідання «Зимового вечора» (1887), що тематично, і за способом осмислення життєвого матеріалу, і за принципами втілення художньої форми відрізняється від інших творів на селянську тематику. Водночас, як це помітив Г. Вервес, $€$ типологічно спорідненим 3 творами української літератури, зокрема оповіданнями I. Франка, передусім «На дні», «Ліси і пасовиська» [1, с.243].

Оповідання I. Франка «На дні» наштовхнуло письменницю розповісти історію морального падіння людини «на дно» суспільства, 3'ясувати соціальну мотивацію злочину. Герої цих творів - представники «суспільного дна» - Ясько або Бонк («Зимового вечора») і Бовдур («На дні»). Схожість цих персонажів виявляється як на ідейно-тематичному рівні, так і в засобах поетики характеротворення. Аналізуючи соціальну мотивацію злочину, письменники вказують на майже схожі етапи моральної деградації персонажів, їх падіння на «дно життя». Автори звертаються до ретроспективних екскурсів у біографії цих героїв, які мали всі умови жити чесно і працювати «в поті чола».

Важливою рисою поетики характеротворення аналізованих творів $\epsilon$ портретна характеристика, причому обидва письменники фіксують увагу на такій художній деталі, як «руки». Так, звироднілий Бовдур «се людина робуча», бо мав на відміну від зовнішніх огидних рис «сильні і здорові руки» [4, с.124]. Така контрастна деталь підкреслює колись вироблену в нього звичку до праці. Цю саму деталь виводить й Е.Ожешко в образі Бонка: «Незнакомец сел на табурет...и принялся крепко растирать длинные красные руки с опухшими пальцами» [3, с.482]; «Его длинные, худые, красные руки поспешно схватили хлеб...» [3, с.484]. 
Злочинні нахили цих персонажів ніби нівелюють їх спогади про дитинство, людські почуття. Так, Бонк неодноразово згадує себе гарною i допитливою дитиною, що зростала в умовах щасливих, безтурботних дитячих років. Бовдур теж згадує майже щасливі хвилини свого життя, коли він був змушений втікати до Борислава і знайшов там краплю людського щастя - дружбу і кохання: «В Бориславі, при корбі, Бовдур і стоваришувався перший раз у своїм житті з одним таким же круглим сиротою, як і сам. Щира була людина, і Бовдур через чотири роки жив 3 ним, як з рідним братом» [4, с.151]. Але і в цих щирих, теплих спогадах Бовдура запеклась злість на всіх без розбору. Саме як «психопатологічний тип» визначає цей образ відомий літературознавець I. Денисюк: «Патологія Бовдура, генезис психології злочину - у його соціальній долі. Людина, яка не зазнала в житті ні ласки, ні добра, навіть при стику 3 добром реагувала на нього злом» [2, с. 97].

Схожий «патологічний тип» змальовує й Е. Ожешко в образі Бонка, хоча він суттєво відрізняється від образа Бовдура своєю життєвою долею. Очоливши селянський бунт, Ясько опинився за гратами. Молодий і недосвідчений, він швидко потрапив під вплив кримінального оточення, спустився на «дно життя». Від нього відмовляється навіть рідний батько. Очевидно, під впливом Франка письменниця в осмисленні цього образа керувалась ширшими світоглядними позиціями, адже Бонк, як і Бовдур, потрапляє на «дно суспільства» не як кримінальний злочинець, а як «свідомий бунтар, як політичний противник існуючого суспільного устрою» [1, с. 244].

В образі Бонка домінують такі характеротворчі деталі й епітети, як «швидкий погляд», «охриплий, скрипучий голос», «довгі, худі, червоні руки», «худий», «сильний». Особливо акцентується увага на епітеті «самотній» та його смислових еквівалентах: «Издали, низом, по самой реке шла какая-то одинокая фигура...Между вздымавшимися по обе стороны высокими склонами человек выглядел маленьким и хрупким, словно былинка, плывущая по беспредельным просторам моря» [3, с. 471]. Цей прийом письменниця використовує як кільцеве обрамлення, чим посилює драматизм цього образу.

Цікаво, що в цих звироднілих соціальних типах обидва письменники залишають жарину людського каяття, на дні душі іскру людяності, що в момент психічного напруження спалахує востанне. Утім, у розкритті цих образів автори вдавалися до різних художніх прийомів. Зокрема, огидну сутність Бовдура ми сприймаємо через безпосередні вчинки та дії героя. А ось потворна сутність Бонка передається опосередковано, - через враження та розповіді рідних чи односельчан про злочинця-каторжника. Саме з розповіді рідного брата постає перед нами страшний злочинець, 22 
якого слід виловити як дикого звіра i покарати на смерть. Ніхто із знайомих не допускає й крихти людського співчуття до нього.

Також висвітленню образів були підпорядковані такі основні прийоми психологічного аналізу, як змалювання зовнішнього виразу психіки героя, наприклад, «мертвий блиск гнилизни» у виразі очей Бовдура та «внутрішня відчуженість» у постаті і поведінці Бонка; відображення самого процесу мислення, пульсації думок у їх приливах i відпливах на зразок психологічного дуету думок. Так, до прикладу, у свідомості Бовдура відбувається боротьба задуму зарізати Темеру, щоб відібрати в нього гроші, із слабкими спробами протесту совісті проти задуманого злочину.

Утім образ Бонка глибоко індивідуалізований, він має свої риси, свою вдачу, свої глибоко психологічні мотиви морального падіння. Та i художній підхід у розкритті цього персонажа в Ожешко свій, адже, на відміну від франківського, цей образ центральний у творі, і всі події відбуваються через сприйняття цього героя. Хоча форма оповіді, як і у Франка, - авторська, новелістична. Обидва твори характеризують - часова і просторова обмеженість подій та специфічна трагічнодраматична сюжетна напруга; а також два способи побудови: повістевий і новелістичний; спільним $є$ і спосіб авторської характеристики героїв, функції оповідача. Певне місце в цих творах відведено засобам фольклору (пісні, легенди, загадки, народна лексика), що дозволяє осмислити філософсько-етичну сутність життя народу, його мислення та вчинків. У творі Ожешко фольклорному та етнографічно-побутовому фону відведено чимало місця.

Отже, І.Франко та Е.Ожешко, у типологічно подібних творах «На дні» і «Зимового вечора», вивівши певні суспільні типи, підкреслили насамперед соціальну мотивацію злочинності. Вони показали процес деградації особистості, виявили причини опускання людей на «дно суспільства». У цьому плані герой Ожешко доповнює цілу галерею франківських героїв «дна».

\section{Література:}

1. Вервес Г. Д. Іван Франко і питання українсько-польських літературно-громадських взаємин 70-90-х років 19 ст. К.: Вид-во АН УРСР, 1957. $363 \mathrm{c}$.

2. Денисюк I. О. «Суспільно-психологічна студія або «живопись дна». Українське літературознавство. 1968. №5. С. 92-99.

3. Ожешко Э. Сочинения: В 5 т. М.: Худ. лит., 1953. Т. 5.571 с.

4. Франко І. Я. Зібрання творів: У 50 т. - К.: Наукова думка, 19761986. T. 15. C. 110-163. 